'Clinical sepsis' was considered to be present if clinical and/or haematological signs were recorded. If, in addition to these, a positive blood culture was recorded, the sepsis was defined as 'bacteriologically confirmed'. Central catheters were used only sparingly in the Netherlands, and total parenteral nutrition was administered mostly by peripheral infusion. Blood cultures were seldom taken routinely, even in infants treated by total parenteral nutrition. Only clinical evidence of sepsis justifies such a procedure in these very small infants.

Dr Puntis misread the part about causative organisms. Far from considering these benign, we stated that in infants treated by total parenteral nutrition the causative organisms were 'fairly benign' namely, compared with infants not treated by total parenteral nutrition; this point is illustrated even better by our original unpublished table, categorising the causative organisms by duration of total parenteral nutrition (see table).

Table Causative organisms of bacteriological sepsis by duration of total parenteral nutrition, as percentage of cases in each group.

\begin{tabular}{llllll}
\hline $\begin{array}{l}\text { Duration } \\
\text { of total } \\
\text { parenteral } \\
\begin{array}{l}\text { nutrition } \\
\text { (days) }\end{array}\end{array}$ & S epidermidis & $S$ aureus & E coli & $\begin{array}{l}\text { Strepto- } \\
\text { coccus } \\
\text { group } B\end{array}$ & Other \\
\hline 0 & 4 & 11 & 25 & 29 & 32 \\
$1-7$ & 27 & 19 & 19 & 16 & 19 \\
$8-28$ & 36 & 26 & 20 & 7 & 11 \\
$>28$ & 67 & 17 & - & - & 16 \\
\hline
\end{tabular}

Quite correctly, Dr Puntis points out that no conclusion can be drawn from our data as to the aetiology of sepsis related to total parenteral nutrition. As the administration of total parenteral nutrition, however, both by peripheral and by central systems, carries the risk of introducing micro-organisms by infected fluids ${ }^{1}$ or systems, ${ }^{2}$ a causal relation is plausible. In addition to the strong association between sepsis and total parenteral nutrition emerging from our multivariate statistical analysis this justifies our conclusion that total parenteral nutrition is an important risk factor for sepsis in such infants.

We do not share Dr Puntis' view that total parenteral nutrition was overused. The study population contained, by definition, almost exclusively infants with immature digestive systems, which renders non-use of total parenteral nutrition the exception. Next to recent improvements in ventilatory support systems, total parenteral nutrition as the source of adequate nutrition is one of the most obvious factors contributing to the trebled rate of intact survival of such infants in the past 20 years. ${ }^{3}$

\footnotetext{
References

1 Fleer A, Sanders RC, Visser MR, et al. Septicemia due to coagulase-negative staphylococci in a neonatal intensive care unit: clinical and bacteriological features and contaminated
}

parenteral fluids as a source of sepsis. Pediatr Infect Dis 1983;2:426-31.

2 Puntis JWL. Percutaneous insertion of central venous feeding catheters. Arch Dis Child 1986;61:1138-40.

3 Verloove-Vanhorick SP, Verwey RA. Project on preterm and small for gestational age infants in the Netherlands 1983. Leiden: Rijksuniversiteit, 1987. 377 pp. (Thesis).

\section{Plasma amino acids in preterm infants fed on human milk or formula}

Sir,

We read with interest the paper by Ventura and Brooke and were surprised that they stated there were few data on amino acid concentrations in babies fed the new low birthweight formulas or on babies fed breast milk. ${ }^{1}$ Two years ago we published amino acid profiles on 85 low birthweight infants as part of a randomised controlled trial comparing different low birthweight formulas and expressed breast milk. ${ }^{2}$ Like Ventura and Brooke we found higher total amino acids in low birthweight babies fed formulas compared with those fed breast milk, but we also showed different concentrations of three amino acids depending upon type of low birthweight formula (table).

Table Comparison of selected amino acids in formula fed babies. Results are mean (SD)

\begin{tabular}{lccc}
\hline $\begin{array}{l}\text { Amino acid } \\
(\mu \text { molll })\end{array}$ & $\begin{array}{l}S M A \text { LBW } \\
(n=25)\end{array}$ & $\begin{array}{l}\text { Prematalac } \\
(n=25)\end{array}$ & $\begin{array}{l}\text { Preaptamil } \\
(n=25)\end{array}$ \\
\hline $\begin{array}{l}\text { Phenylalanine } \\
\text { Cystine }\end{array}$ & $45(9)$ & $56(15)$ & $53(22)$ \\
Lysine & $27(7)$ & $29(8)$ & $39(11)$ \\
\hline
\end{tabular}

Analysis of variance $\mathrm{p}<0.05$.

For these three amino acids, babies fed Preaptamil had the highest and babies fed SMA-LBW the lowest concentrations.

Therefore we feel Ventura and Brooke were wrong to group together all amino acid results on babies fed different formulas as the type of formula may determine amino acid concentration.

\section{References}

1 Ventura V, Brooke OG. Plasma amino acids in preterm infants fed on human milk or formula. Arch Dis Child 1987;62:1257-64.

2 Bell AH, Halliday HL, McClure G, Reid M. Controlled trial of new formulae for feeding low birth weight infants. Early Hum Dev 1986;13:97-105.

A H Bell, H l Halliday, G McClure, and M McC ReID Royal Maternity Hospital, Grosvenor Road, Belfast BT12 $6 B B$ 